\title{
STEĆCI - MEDIEVAL TOMBSTONES AS GREAT POTENTIAL FOR DEVELOPMENT OF TOURISM IN WESTERN HERZEGOVINA REGION
}

\author{
Edita Vučićc ${ }^{22}$ \\ Jelena Putica $^{23}$
}

\begin{abstract}
Stećci - medieval tombstones, in all aspects of their appearance, represent a specific segment of cultural and historical heritage of Bosnia and Herzegovina, the western parts of Serbia and Montenegro and the central or southern parts of Croatia. (UNESCO, 2105, 123)

This paper analyses current situation of the medieval necropolises of tombstones in western Herzegovina in order to draw attention to insufficient valorisation in the tourist offer, despite the fact that this cultural heritage is on the UNESCO World Heritage List.

The situation on the field, points to the conclusion that cultural and historical heritage is not particularly appreciated in the local or wider context.

Collective awareness of its conservation is at a low level, because of insufficient knowledge of the same matter. Medieval tombstones disappear daily because of the climate change and atmospheric action, inadequate legal protection, but also insufficient education of human factor. Survey research was conducted with the local population, which is a key factor for a higher degree of valorisation in the analysed area. The main goal is to get to know and educate the population about the importance of the tombstones, which have left a significant trace in the culture and traditions of modern times.
\end{abstract}

Key words: tombstones, culture, Herzegovina, tourism

\section{INTRODUCTION}

There is not a universal definition of cultural tourism given that different authors, in accordance with available resources, have different approach to the term of cultural place in which they are situated but also contribute to their conservation. Besides the term of cultural tourism, very often there are other terms in the literature such as: cultural heritage, cultural tradition and similar. According to Dictionary of Travel, Tourism and Hospitality cultural tourism is defined, as a general term that relates to leisure time travel motivated by one or more cultural factors of a certain space. (Harris, Howard, 1996).

Richards (1996) in his work Cultural tourism in Europe defines culture as a composite unit that is based on organisational concept of broad spectrum of lifestyle. With this comprehensive definition the author has given broader possibilities to perceive cultural tourism that do not necessary embrace a visit to cultural attractions. The visit to every

\footnotetext{
${ }^{22}$ Teaching Assistant, Department of Geography, Faculty of Science and Education; Faculty of Humanities and Social sciences, University of Mostar, Mostar, Bosnia and Herzegovina

${ }^{23}$ Teaching Assistant, Department of Geography, Faculty of Science and Education, University of Mostar, Mostar, Bosnia and Herzegovina
} 
new tourist destination, interaction with their inhabitants is also introduction to cultural tradition. The World Tourism Organisation (WTO) interprets detailed definition of cultural tourism, according to which it is "movement of people because of basic cultural motivations, such as study tours, artistic and cultural tours, travel on festivals and other cultural events, visiting historical areas and monuments, travel to learn about nature, folklore or art or pilgrimage. That type of tourism meets the needs for different cultural experience and looks for possibilities to increase cultural level, knowledge of experience, and encounters" (WTO, 1995).

Culture can be both primary and secondary motive of tourist travel. Primary motive have those tourists who plan their travel because of a certain cultural event or visit to cultural attractions. Secondary motive is defined by those tourists who, within their travel, have also included a visit to some of cultural attractions or events.

Cultural tourism resources can be divided into:

1. Monuments

- sacral monuments

- public monuments

- historical buildings

- castles and palaces

- parks and gardens

- fortresses

- archaeological areas

- industrial - archaeological buildings

2. Museums

- folklore museums

- art museum

3. Routes

- $\quad$ art routes

- cultural - historical routes

4. Entertainment centre

- cultural - historical centres

- archaeological centres

- architectonic centres

- music centres

5. Cultural - historic events

- religious festivals

- secular festivals

- folklore festivals

6. Artistic events

- exhibitions

- festivals (adapted from: Pančić-Kombol, 2006). 


\section{METHODOLOGY}

During the research non-destructive field work methods such as detailed research of the sites with medieval tombstones using topographic maps, web satellite images, local population interview and current literature review were used. The aim was to determine actual situation on field to get completely exact data, which served as a basis for the analyses mentioned in this paper. The result was increased number of medieval necropolises and tombstones than it was recorded in the literature. (Figures 2, 3, 4, 5).

Questionnaire on local population (100 examinees) was used as a research method. Out of 100 examinees, $26,5 \%$ were male and $73,5 \%$ were female. Examinees had to answer 15 questions of closed type. Research was conducted with on-line questionnaire during the time period from June to August 2017. Regarding the education level, 58,2\% of the examinees had Master degree, high school education 24,5\%, and Doctoral degree 17,3 $\%$. Concerning the age of the examinees $87,8 \%$ were $20-60$ years old, $11,2 \%$ were $0-19$ years old and $1 \%$ were over 60 years old. Collected data were processed in Excel.

\section{Medieval tombstones - stećci at the area of western Herzegovina}

Western Herzegovina is a region placed in south-western part of Bosnia and Herzegovina. It consists of two relief units, namely area of Low Herzegovina 1/5 and High Herzegovina 4/5.

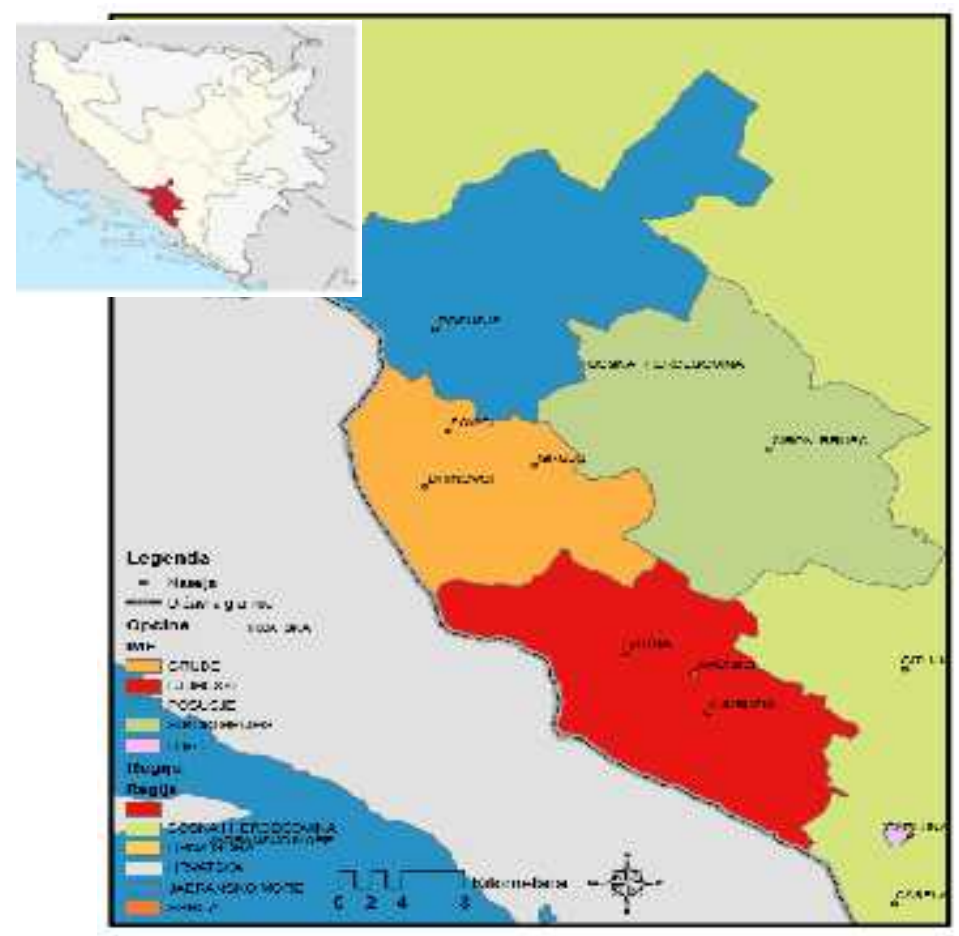

Fig. 1. Geographical position of western Herzegovina $1267 \mathrm{~km}^{2}$

Source: Authors, 2017. 
The borders of western Herzegovina are Čabulja mountain ridge, a part of Čvrsnica, Oštrec and Zavelima on north, and on south and southwest there is a border with the Republic of Croatia. According to Šimunović, the geographic borders of west Herzegovina are matching the administrative borders of West Herzegovina Canton. (Šimunović, 1997, 125-144). (Fig. 1.). Administrative-territorial area of West Herzegovina Canton is divided on the area of Šroki Brijeg City, and municipalities of Ljubuški, Grude and Posušje.

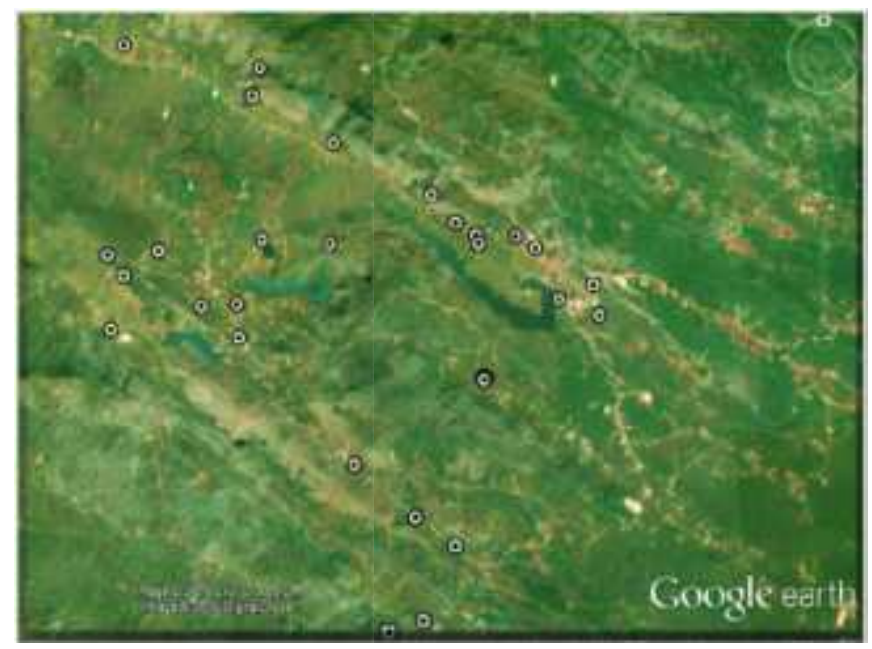

Fig. 2. Necropolises in municipality of Grude Source: Authors 2017.

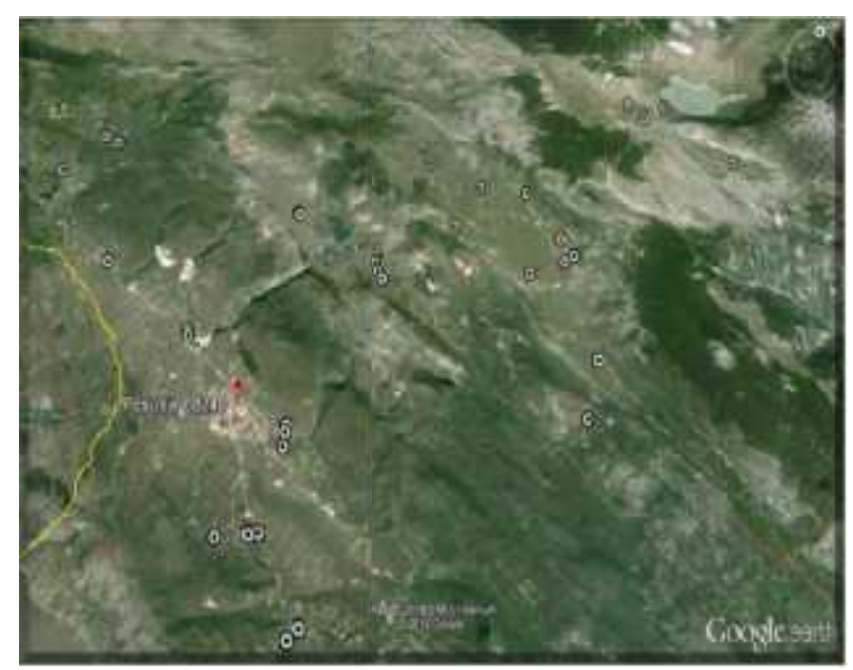

Fig. 3. Necropolises in municipality of Posušje Source: Authors 2017. 


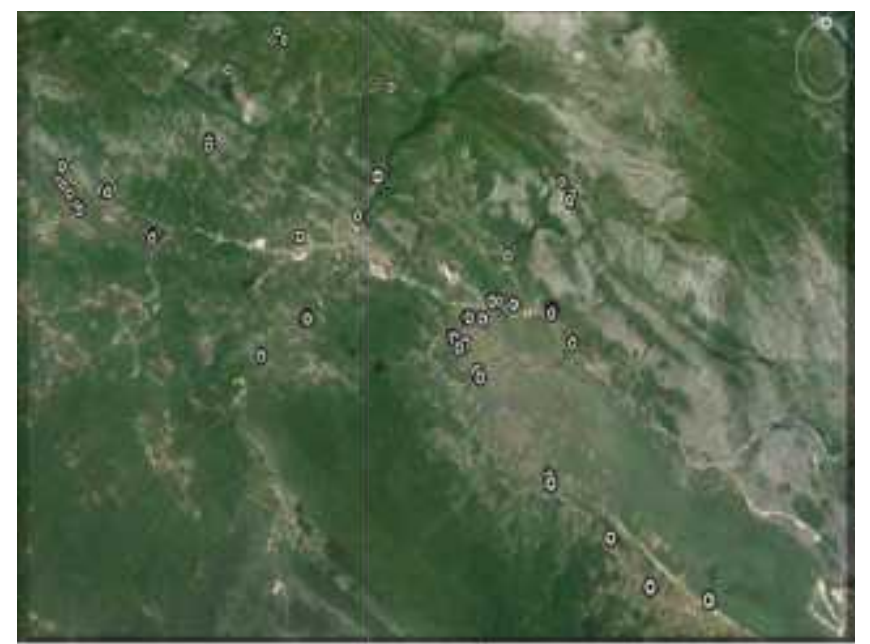

Fig. 4. Necropolises in Šroki Brijeg City

Source: Authors 2017.

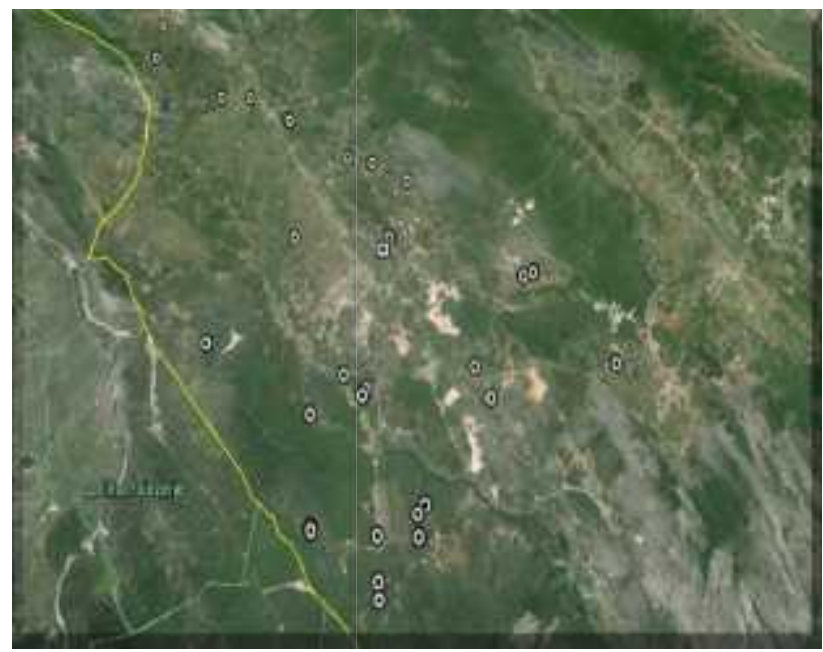

Fig. 5. Necropolises in municipality of Ljubuški

Source: Authors 2017

Representation of necropolises of medieval tombstones in certain municipalities is shown in the Figures 2, 3, 4, and 5, and it is based of authors' field work.

Term stećak refers to a tombstone that is characteristic for the time period of developed and late Middle Ages. Out of 70,000 registered tombstones on 3,300 sites there are 60,000 in Bosnia and Herzegovina, 4,400 in Croatia, around 3,500 in Montenegro, and around 4,100 in Serbia. (Bešlagić, 1982; Bešlagić, 2004).

Although, data in literature indicate appearance of tombstones from the late $12^{\text {th }}$ century, it certainly can be claimed that these tombstones were intensively made during the $14^{\text {th }}$, the $15^{\text {th }}$ and at the beginning of the $16^{\text {th }}$ century when they slowly started disappearing. The importance of medieval tombstones is additionally emphasised by 
their acceptance for UNESCO List of Protected Monuments (Figure 6. necropolis Bijača in municipality of Ljubuški is the only necropolis from West Herzegovina Region on the UNESCOs List of Protected Monuments).

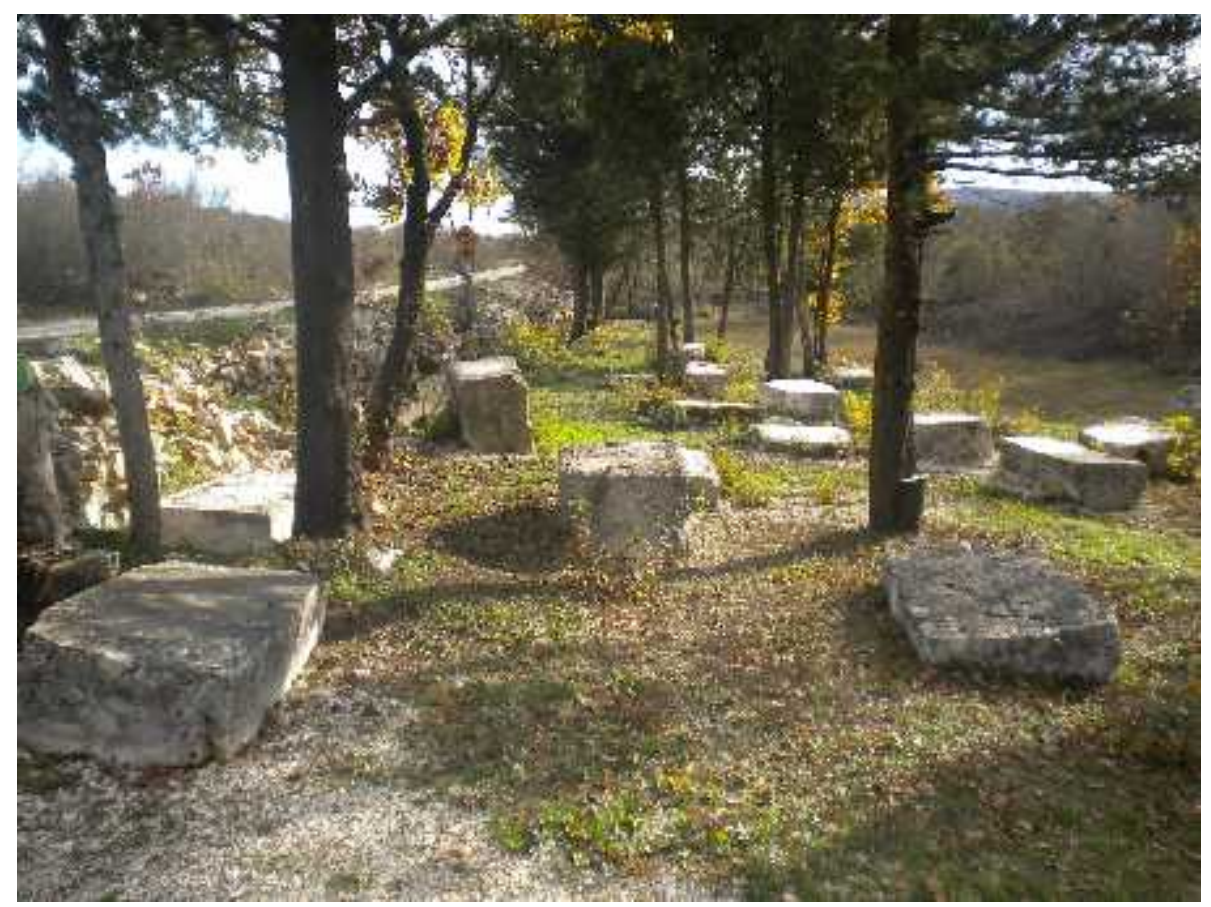

Fig. 6. Bijača necropolis - UNESCO

Source: Authors 2016.

Due to dominant and specific location where they emerged, the shape of tombstones, motives and inscriptions on them, since the $17^{\text {th }}$ century stećci have started to attract the attention of highly educated western circles. The first papers concerning late Middle Ages necropolises in western Herzegovina were mostly related to their short descriptions, listing and sporadic interpretation of their symbolism. At the end of the $19^{\text {th }}$ century the medieval tombstones have become the subject of multidisciplinary research of both domestic and foreign experts, after Austro-Hungarian occupation and establishment of the National Museum in Sarajevo in 1888. The first systematic listing of late Middle Ages necropolises of Bosnia and Herzegovina has started in 1960s and 1970s and has been initiated by the National Museum's archaeologists, followed by publication of 9 monographies. There are two monographies related to the medieval necropolises in Široki Brijeg and Ljubuški municipalities, as well as review on necropolises in Grude municipality. (Benac, 1952; Vego, 1954; Vego, 1964) Some of more significant necropolises within the area of West Herzegovina are certainly Bijača, Grabovine-Zvirići, Kočerin, Ledinac, Mramorje, Šarampovo-Uzarići, Kočerin-Lipovci, Varda etc. 


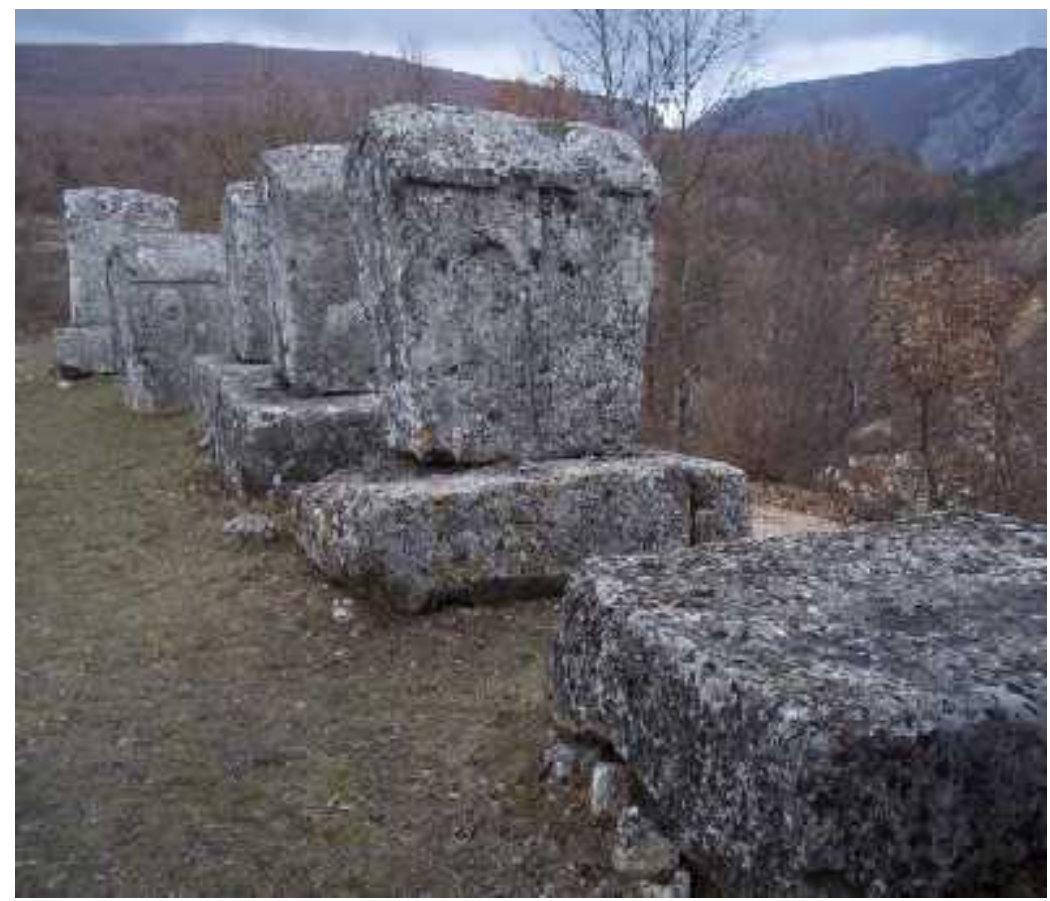

Fig. 7. Ričine necropolis

Source: Authors 2017.

\section{Tourist valorisation of stećci at the area of western Herzegovina}

Cultural heritage makes an important resource of western Herzegovina tourist offer, which unfortunately is not sufficiently valorised in terms of tourism. Rich cultural heritage gives an opportunity to this part of Bosnia and Herzegovina to be recognisable destination of cultural tourism with its authenticity. Changes in lifestyle, higher level of education and other socio-cultural changes lead to increased demand for selective forms of tourism and thus cultural tourism. Thanks to positive trends in tourist demand growth, cultural tourism at this part of Herzegovina has bright future. Culture can be primary, secondary and random motive of tourist travels. ${ }^{24}$

When it comes to western Herzegovina, cultural tourism is not the primary motive of tourist arrivals, but with greater dedication of local and state authorities it is, certainly, one of the biggest potentials. Herzegovina should seek an opportunity in cultural tourism to extend tourist season and to develop tourism throughout whole year (Humac, Široki Brijeg, Grude). The pilgrims who come to Međugorje, worldwide known religious destination, might also visit nearest cultural destinations in West Herzegovina.

${ }^{24}$ Primary tourist destination is the one that is being visited solely for the purpose of participating in its cultural offering. In secondary tourist destination a tourist is attracted by some other motivation, such as sun and sea with cultural offering not being a priority. Accidental destination means that a tourist did not intend to visit it but during their travels they came into contact with locals and that's how they get introduced to their culture. 
Culturists are mostly those persons who have higher or high level of education, and therefore higher standard that makes them good consumers at some destination.

The inclusion of stećci necropolises in Herzegovina's tourist offer requires a certain degree of financial resources, but also a number of provisions to protect them from natural and anthropogenic deterioration. It is necessary to regulate traffic access to certain sites, necropolises protect, work on the better promotion of the cultural heritage itself (brochures, promotion at fairs and the Internet). Also, cultural resources and sightseeing are not enough, they need to create attractions in order to get visitors to get acquainted with historical and cultural value, but to make the visit of attractions attractive and cause a certain part of the emotions (Vrtiprah, 2006). Cultural tourism could become important issue in conserving and promoting of the culture and tradition of West Herzegovina.

\section{RESEARCH RESULTS}

Collected data analysis has shown very low visits of local population to necropolises (Fig. 8). The highest number of examinees have visited the necropolises in Kočerin, Bijača and Zvirići, while Mramorje, Ričine (Figure 7), and Šarampovo were the least visited necropolises. More than $40 \%$ of examinees have not visited any of necropolises, and $60 \%$ of them did not know that the Bijača necropolis is on the UNESCO World Heritage List. Having regard that more than $60 \%$ of examinees, who took part in this research, have higher level of education, we have to emphasise that this data is alarming.

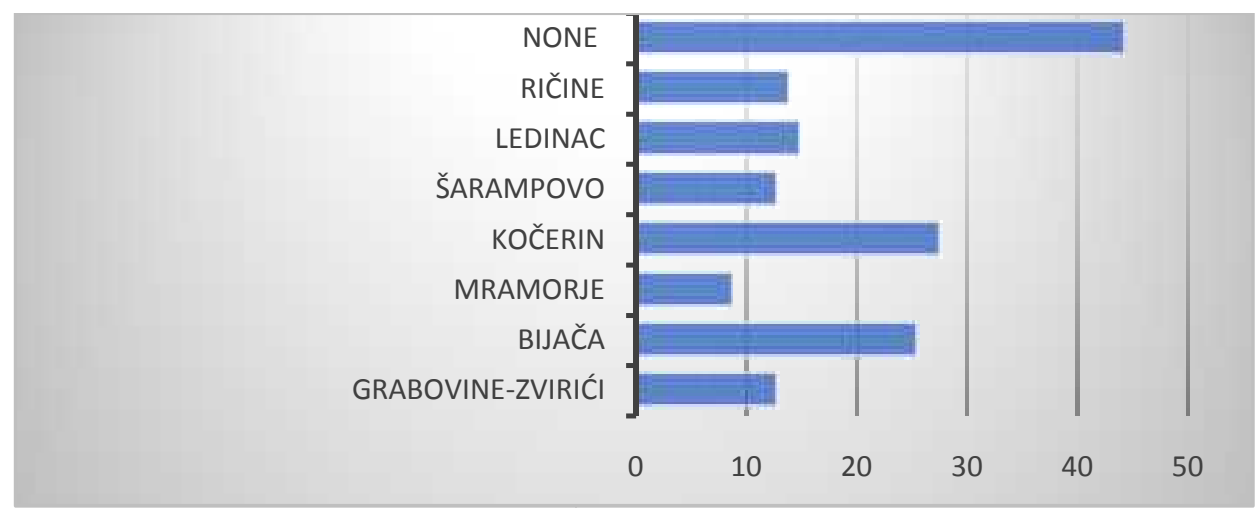

Fig. 8. Visiting rate of necropolises in western Herzegovina/percentage of visitors

Source: Authors based on survey in 2017.

The authors suggest, as a solution of this problem, necessary change of curricula in which studying of cultural-historical heritage is insufficiently represented, and also additional organisation of expert seminars and workshops to promote above-mentioned cultural destinations better. 
When it comes to characteristics of stećci (origin, age, motives they are decorated withfigure 10 and 11), $21 \%$ of examinees are familiar with them, while over $50 \%$ of them are only partially familiar with. (Bešlagić, 1982; Miletić, 1982; Wenzel, 1965).

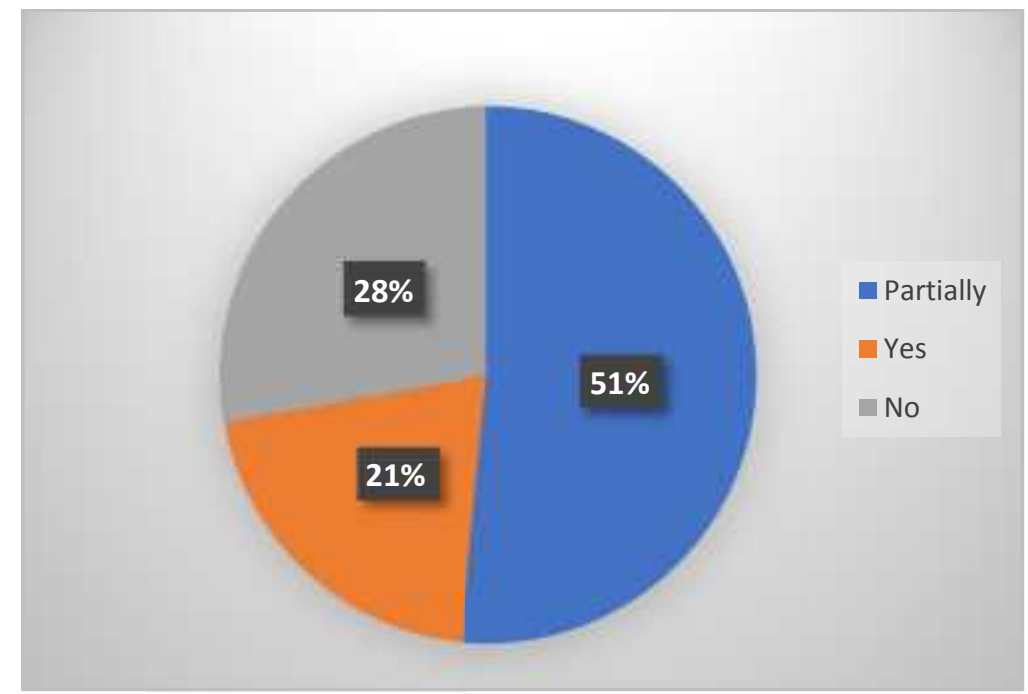

Fig. 9. Local population knowledge of medieval tombstones' characteristics (origin, age, motives)

Source: Authors based on survey in 2017.

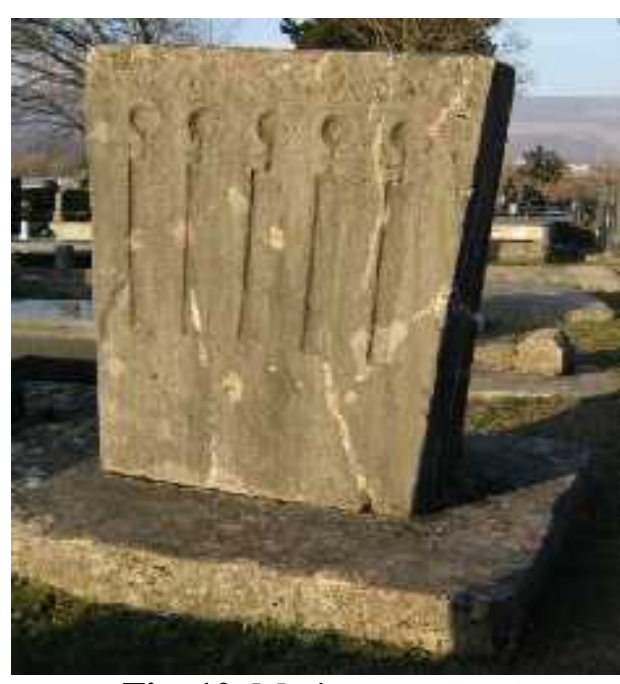

Fig. 10. Motives on stećci

Source: Authors 2017

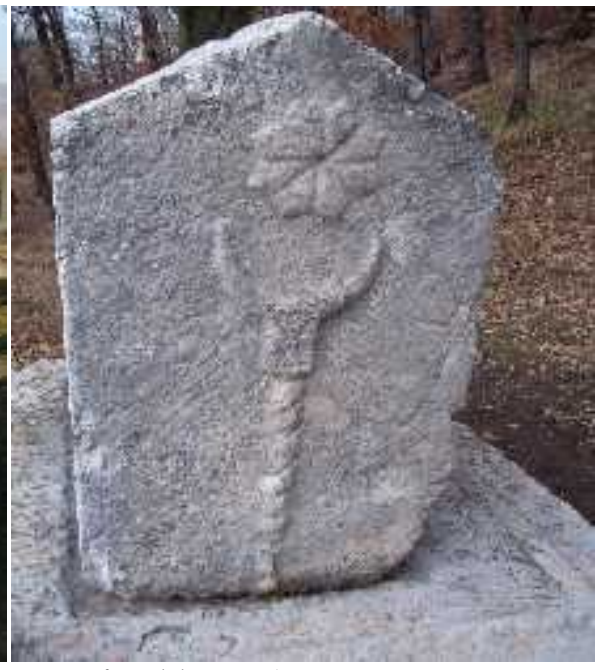

Fig. 11. Motives on stećci

Source: Authors 2017.

When it comes to tourist valorisation of stećci, only $4 \%$ of examinees consider that stećc $i$ are sufficiently represented in tourist offer of Herzegovina. It has been concluded that Tourist Association have to create new plans and programmes for management of cultural assets and work on implementation of them in due time by employing new 
staff. Stronger engagement of public sector is necessary, as well as cooperation at local and regional level in order to open new markets, and fostering local entrepreneurship for sake of making promotion materials and opening of catering facilities. The research has also analysed satisfaction of local population with education of persons employed in tourist sector. The results are shown by Likert scale (Figure 12).

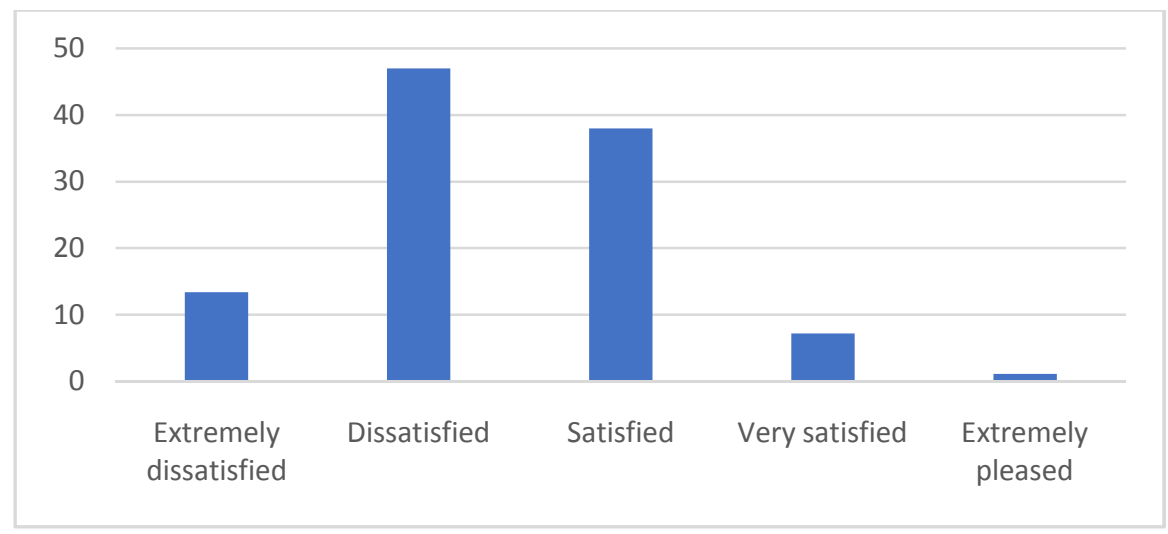

Fig. 12. Level of local population satisfaction with education of employees in tourist sector

Source: Authors based on survey in 2017

The highest number of examinees, over $50 \%$ is dissatisfied with education of employees in tourist sector and with their knowledge about cultural-historical heritage of the region. Since this concerns resources that have inestimable value, it is necessary to engage public sector and to not only establish higher cooperation with the public sector but also local population. Due to a general lack of education, but also inadequate functioning of authorised bodies and institutions responsible for protection of culturalhistorical heritage at the area of western Herzegovina, great number of necropolises is endangered with human activities, and some of them are either partially or completely destroyed.

\section{CONCLUSION}

The research has been conducted with the aim to indicate general state of indifference in context of cultural-historical heritage of western Herzegovina presentation. Field work/research has confirmed that great number of necropolises, and also other archaeological units are abandoned to deterioration because of both atmospherics activities and irresponsibility of human factor. Registering stećci on the UNESCO World Heritage List, their importance has been emphasised in context of world material and non-material heritage, but that importance is not recognised at local level.

The situation described in this paper is also exacerbated by the problem of lack of archaeological research and anthropological analyses of osteological materials, which 
would serve as the main indicators for reconstruction and interpretation of lifestyles of late medieval populations that would greatly strengthen idea of their inclusion in tourist offer. We are of the opinion that it is necessary to make changes in curricula and educational institutions at all levels with the aim of raising awareness on role and preservation of cultural-historical heritage for all future generations.

\section{REFERENCES}

1. ARHEOLOŠKI LEKSIKON Bosne i Hercegovine, Tom 3, (1988), Zemaljski muzej Bosne i Hercegovine, Sarajevo

2. BENAC, Alojz, (1952), Široki Brijeg, Srednjovjekovni nadgrobni spomenici Bosne i Hercegovine, III., Zemaljski muzej, Sarajevo

3. BEŠLAGIĆ, Šefik, (1971), Stećci. Kataloško-topografski pregled, Veselin Masleša, Sarajevo

4. BEŠLAGIĆ, Šefik, (1971a), Stećci i njihova umjetnost, Zavod za izdavanje udžbenika, Sarajevo

5. BEŠLAGIĆ, Šefik, (1982), Stećci-kultura i umjetnost, Veselin Masleša, Sarajevo

6. BEŠLAGIĆ, Šefik, (2004), Leksikon stećaka, Svjetlost

7. HARRIS, R., HOWARD, J., (1996), Dictionary of Travel, Tourism and Hospitality Terms',Hospitality Press, University of Cornell

8. MILETIĆ, Nada, Stećci, Umetnost na tlu Jugoslavije, Beograd-Zagreb-Mostar, 1982.

9. PANČIĆ, KOMBOL, Tonka, (2006), Kulturno nasljeđe i turizam, Radovi Zavoda za znanstveni rad, HAZU, br. 16-17., str. 211-226., Varaždin.

10. RICHARDS, Greg, (1996), Cultural Tourism in Europe, CAB, International, str. 8-26.

11. STEĆCI, Medieval tombstones, Nomination Document for the Inscription on the UNESCO world Heritage list, 2015

12. ŠIMUNOVIĆ, Vjekoslav, (1997), Hijerarhija centralnih naselja zapadne Hercegovine, Acta Geographica Croatica, 32., str. 125-142.

13. VEGO, M., (1954), Ljubuški, Srednjovjekovni nadgrobni spomenici Bosne $i$ Hercegovine, sv. VI, Zemaljski muzej u Sarajevu, Sarajevo

14. VEGO, M., (1964), Bekija kroz vijekove, Narodni univerziteti Grude i Posušje, Sarajevo

15. VRTIPRAH, V., (2006), Kulturni resursi kao činitelj turističke ponude u 21. st., Ekonomska misao i praksa, No 2. , str, 279-296.

16. WENZEL, M., (1965), Ukrasni motivi na stećcima, Veselin Masleša, Sarajevo World travel organisation (1995), The state' s role in protecting and promoting culture as a factor of tourism development and proper use and exploitation of the National cultural heritage of sites and monuments for tourism, Madrid. 